\title{
The case for a national whole-of-government anti-corruption body
}

\section{Harry Hobbs and George Williams}

Faculty of Law, University of NSW, Australia

\begin{abstract}
Australia's anti-corruption system needs reform. The diffusion of responsibilities across multiple agencies risks under-reporting of corrupt conduct, while gaps in the regime mean that the system fails to hold people accountable. As a result, community and public confidence in Australia's institutions is eroded. The solution is a national whole-ofgovernment anti-corruption body encompassing the public sector with the power to apply a uniform standard of corrupt conduct.
\end{abstract}

\section{Keywords}

anti-corruption, national integrity commission, institutional trust

\section{Corresponding author:}

Harry Hobbs, UNSW Law, University of New South Wales, Sydney NSW 2052, Australia

Email: h.hobbs@unsw.edu.au

On 8 February 2017, the Australian Senate established a Select Committee to inquire and report on the establishment of a national integrity commission. This Committee follows on from the 2016 Select Committee on the Establishment of a National Integrity Commission which lapsed on 9 May 2016 at the dissolution of the Parliament for the 2 July double dissolution general election. This inquiry comes at a time of renewed focus on Australia's anti-corruption and integrity system. In particular, while every Australian state has a whole-ofgovernment specialist anti-corruption agency, ${ }^{1}$ efforts to introduce a similar body at the federal level have so far been resisted. ${ }^{2}$ In this article, we explore Australia's existing anticorruption regime. We identify two major problems that arise from the current system and argue that these challenges have a causal relationship to declining trust in Australia's democratic institutions. We argue that a national whole-of-government anti-corruption body will resolve the problems we identify, and assist in arresting waning faith in government.

\footnotetext{
${ }^{1}$ NSW: Independent Commission Against Corruption (1988); Qld: Crime and Corruption Commission (1991); WA: Crime and Corruption Commission (1992); Tas: Integrity Commission Tasmania (2010); Vic: Independent Broad-based Anti-Corruption Agency (2012); SA: Independent Commissioner Against Corruption (2012).

${ }^{2}$ See, eg, 'Government rejects call for federal ICAC', Sky News, 16 December 2016 http://www.skynews.com.au/news/top-stories/2016/12/16/government-rejects-call-for-federal-icac.html.
} 


\section{The existing system: The multi-agency approach}

Australia's existing anti-corruption and integrity system divides responsibilities across several Commonwealth agencies. Characterised as the 'multi-agency' approach, this framework empowers different institutions with 'specific responsibilities for tackling corruption in different levels of government, and in relation to specific types of corruption'. ${ }^{3}$ It is premised on the fact that 'the risks of corruption in the Australian Public Service vary according to each agency's operating environment', and that anti-corruption efforts will be best realised when each agency 'consider[s] their own risk profile[] and take[s] reasonable measures to mitigate risks'. ${ }^{4}$ However, as Professor AJ Brown has explained, a 'multi-faceted approach is not automatically a comprehensive approach'. ${ }^{5}$ Indeed, at present, Australia's legislative, institutional and policy framework governing all facets of institutional, organisational, political and electoral, and individual corruption and misconduct is under-inclusive and unwieldy.

Our article centres on two difficulties that arise from the multi-agency approach. First, the existence of multiple agencies with responsibility for detecting and investigating corrupt conduct makes it difficult for persons alleging such conduct to know which body they should approach in order to make their allegations, resulting in under-reporting and confusion. Second, despite the proliferation of anti-corruption agencies, the current arrangements do not apply equally to all sectors of the Australian government. For instance, federal politicians are not subject to legally enforceable anti-corruption accountability mechanisms. Recurring high profile cases of federal parliamentarians behaving outside community expectations indicates that this gap is of significant concern.

\section{Australia's major anti-corruption institutions}

The 2016 Interim Report of the Select Committee on the Establishment of a National Integrity Commission identified several institutions with mandates that encompass the enforcement of public sector integrity and anti-corruption within the Commonwealth sphere. Major institutions are the Australian Commission for Law Enforcement Integrity (ACLEI), the Australian Federal Police (AFP), the Australian Public Service Commission (APSC), the Commonwealth Ombudsman and the Office of the Commonwealth Auditor-General.

Consistent with the Commonwealth's approach, these institutions work within different parts of government and are tasked with investigating and deterring differing types of corruption.

\footnotetext{
${ }^{3}$ Attorney-General's Department, The Commonwealth's Approach to Anti-Corruption (Discussion Paper, 2012) 4.

${ }^{4}$ Australian Public Service Commission, State of the Service Report 2012-2013 (2013) 71.

${ }^{5}$ Evidence to Select Committee on the Establishment of a National Integrity Commission, Parliament of Australia, Canberra, Canberra, 21 April 2016, 10 (Professor AJ Brown).
} 
The ACLEl's primary role is to investigate law enforcement-related corruption, ${ }^{6}$ encompassing oversight of the Australian Criminal Intelligence Commission, the AFP, the Australian Transaction Reports and Analysis Centre, prescribed aspects of the Department of Agriculture and Water Resources, and the Department of Immigration and Border Protection. The AFP investigates serious and complex crimes, including fraud against Australian government programs whether committed within or outside Australia. The APSC is responsible for promoting the Australian Public Service's Values and Code of Conduct and ensuring that government agencies comply with the Code. ${ }^{7}$ Among other values, the Code of Conduct contains principles relating to managing conflicts of interest, and using Commonwealth resources. The Commonwealth Ombudsman undertakes investigations into complaints received from members of the public concerning government administrative action, as well as initiating investigations into systemic problems on its own motion. ${ }^{8}$ Finally, the Commonwealth Auditor-General and Australian National Audit Office independently assess selected areas of public administration and provide assurance about public sector financial reporting, administration and accountability. ${ }^{9}$

There is evidence that these bodies are effective, within their scope of operations, in combating corruption. High-profile instances of corrupt conduct, such as the Australian Wheat Board oil-for-wheat scandal, and the Note Printing Australia and Securency scandal, in which organisations were found to be paying bribes to secure lucrative international contracts, suggests that the multi-agency approach can detect, investigate and prosecute acts of corruption. Indeed, Transparency International places Australia in the top echelon of 'clean' countries. The latest report ranked Australia $13^{\text {th }}$ in the world. ${ }^{10}$ However, there has been a slide in Australia's position: in 2012, for instance, Australia was ranked $7^{\text {th }} .{ }^{11}$ Equally, discovery of even large-scale incidents of corruption is not evidence that all corruption is uncovered. In fact, evidence suggests that two problems beset Australia's current system. First, that the current multi-agency approach may make it difficult for persons alleging corrupt conduct to know which body they should approach to make their allegations, resulting in under-reporting. Second, that gaps in the regime mean some persons avoid being held accountable for corrupt conduct.

The multi-agency approach may under-report incidents of corruption

\footnotetext{
${ }^{6}$ Law Enforcement Integrity Commission Act 2006 (Cth) Pt 13, Div 3.

${ }^{7}$ Public Service Act 1999 (Cth) Pt 5.

${ }^{8}$ Ombudsman Act 1979 (Cth) s 5.

${ }^{9}$ Auditor-General Act 1997 (Cth) Pt 4, Pt 6.

${ }^{10}$ Transparency International, Corruption Perceptions Index 2016 (Transparency International, 2017$) 4$.

${ }^{11}$ Transparency International, Corruption Perceptions Index 2012 (Transparency International, 2012) 3.
} 
Under Australia's multi-agency approach, corruption and misconduct is tackled by different institutions under an ad hoc collection of federal laws. Consequently, it can be unclear which agency is responsible for a matter. In these circumstances, there is a substantial risk that breaches of public trust, dishonesty and corruption may fall between the cracks. This can lead to failures to prevent corruption, and an under-reporting and under-investigation of the problem. In their submission to the 2016 Select Committee on the Establishment of a National Integrity Commission, Gabrielle Appleby, Sean Brennan, Shipra Chordia and Grant Hoole recognised this risk. They explained that diffusing integrity and anti-corruption functions across multiple institutions 'may deny individuals, including citizens and public service employees, a prominent and accessible point of contact for reporting concerns' ${ }^{12}$

This problem at the federal level can be contrasted with approaches at the state level. In New South Wales, for instance, anyone with a lead on corrupt conduct can go to the Independent Commission Against Corruption website, where a prominent 'report corruption here' button invites them to take action. By contrast, at the federal level, people with information can find it hard to know where to start, which may stop them from coming forward. Empirical evidence suggests this risk is a reality. The APSC 2016 Employee Census reported that, over the previous year, more than 3000 federal public servants had seen inappropriate or illegal behaviour at work, including conflicts of interest, nepotism, blackmail, bribery, fraud and collusion with criminals. Disturbingly, only a third reported this behaviour to their supervisor. The larger group said that they were unsure how to report corruption, and so the problem was not properly dealt with. ${ }^{13}$

Earlier APSC Employee Censuses returned similar results. In 2014, almost 2600 public servants reported that they had witnessed another employee engaging in behaviour they considered serious enough to be viewed as corruption. Of these, only 44 per cent reported the behaviour. ${ }^{14}$ In 2015, only 34 per cent of those who witnessed suspected corrupt behaviour, reported it. ${ }^{15}$ There are many reasons why people might under-report corruption in their organisation, including fears of retaliation. Unfortunately, these two earlier surveys did not ask why respondents did not report the alleged corrupt conduct. It appears likely however, that the reasons identified in the 2016 census were important. That is, the proliferation of anti-corruption agencies is confusing.

\footnotetext{
${ }^{12}$ Gabrielle Appleby et al, Submission No. 19 to Select Committee on the Establishment of a National Integrity Commission, 20 April 2016, 12.

13 Australian Public Service Commission, State of the Service Report 2015-2016 (2016) 27-28.

${ }^{14}$ Australian Public Service Commission, State of the Service Report 2013-2014 (2014) 237.

${ }^{15}$ Australian Public Service Commission, State of the Service Report 2014-2015 (2015) 46.
} 
The problem of under-reporting could be rectified by making the existing agencies more prominent so that it was clearer where people could lodge their allegations. For instance, the Commonwealth Ombudsman could serve as a one-stop-shop for any allegation of corruption, and then direct allegations to the appropriate organisation. However, while this may increase reporting, it would not satisfy the second problem with the multi-agency approach: gaps in coverage. One of the most significant gaps concerns the federal Parliament. Only a national integrity commission with a clearly defined role and responsibility could resolve both of these problems.

\section{The multi-agency approach leaves significant gaps in coverage}

Despite the number of institutions dedicated to investigating corruption across government agencies, the breadth of Australia's current anti-corruption system is inadequate. Excepting potential AFP investigations into criminal conduct, there are no independent integrity or anticorruption mechanisms with the authority to monitor the federal Parliament. Instead, members of Parliament are held accountable by soft-law instruments and unenforceable codes of conduct. These include the 2013 Standards of Ministerial Ethics, the Statement of Standards for Ministerial Staff, the Lobbying Code of Conduct, and Register of Lobbyists. While such unenforceable statements are prevalent across the public and private sector, evidence suggests that they are only effective if sanctions apply for their breach. ${ }^{16}$

The Attorney-General's Department justifies unenforceable codes of conduct on the basis that 'robust democratic institutions' are more effective in 'promoting a fair and transparent society and combatting corruption'17 than legally enforceable standards. The Department identifies parliamentary committees, a free media, civil society and Royal Commissions, as democratic institutions that can play this role. Certainly, at times, such institutions have been effective at exposing instances of misconduct. For instance, the 2015 Royal Commission into the Home Insulation Program found that failures of ministers and public servants in the design and implementation of the home insulation program led to the deaths of four men. ${ }^{18}$ Similarly, in recent years the media has been significant in revealing parliamentary expenses scandals. Nonetheless, however robust these democratic institutions may be, they are not designed to perform the systemic anti-corruption role prescribed by the Attorney-General's Department. Although a Royal Commission is a major formal public inquiry with considerable powers, it is ad hoc and can only investigate according to defined terms of reference.

\footnotetext{
${ }^{16}$ Alan Doig and John Wilson, 'The Effectiveness of Codes of Conduct' (1998) 7 Business Ethics: A European Review 140-149.

${ }^{17}$ Attorney-General's Department, above n 3, 11.

${ }^{18}$ Ian Hangar AM QC, Report of the Royal Commission into the Home Insulation Program (Commonwealth of Australia, 2014).
} 
In addition, democratic accountability mechanisms, such as the ballot box, can be blunt instruments. ${ }^{19}$ Voters are unlikely to have complete information about a candidate's behaviour, and may vote for a party based on decisions around the performance of the government and the opposition, rather than an individual. Further, as an inherently political body, Parliamentarians can shield members of their own political party from scrutiny, preventing proper accountability. Relatedly, allegations can take years to resolve, often until public attention has moved on, or the member in question has left Parliament. Recent examples elucidate the failures of the unenforceable soft-law anti-corruption mechanisms that exist for federal politicians.

Over the last few years, repeated scandals involving federal parliamentarians misusing entitlements has raised alarms over Australia's anti-corruption and integrity system.

Revelations that taxpayers have paid for politicians to attend weddings, ${ }^{20}$ undertake book tours, ${ }^{21}$ tour local Canberra wineries, ${ }^{22}$ attend family ski holidays, ${ }^{23}$ sell haircare products, ${ }^{24}$ and fly interstate to inspect and purchase luxury accommodation, ${ }^{25}$ has fuelled public distrust in federal parliamentarians. This distrust is heightened by the process of investigating allegations of entitlement abuse. Since 1998, the Department of Finance and Deregulation has been tasked with this role. The Department investigates internally, asking the member to explain why the expenses were incurred. It also has the power to refer serious matters to the AFP to determine whether proceedings should be brought in court. ${ }^{26}$ However, under this protocol, politicians generally repay expenses that have been wrongly claimed rather than

\footnotetext{
${ }^{19}$ Alysia Blackham and George Williams, 'The Accountability of Members of Australia's Federal Parliament for Misconduct' (2013) 13 Oxford University Commonwealth Law Journal 115, 117.

${ }^{20}$ James Robertson and Jonathan Swan, 'Buck bucks' for MPs Bollywood adventure', Sydney Morning Herald (Sydney), 6 October 2013 http://www.smh.com.au/federal-politics/political-news/big-bucks-for-mps-bollywoodadventure-20131005-2v0wf.html.

${ }^{21}$ Glenn Milne, 'How Taxpayers Helped Tony Abbott Flog Battlelines', ABC News, 29 September 2010 http://www.abc.net.au/news/2010-07-28/35544.

${ }^{22}$ See Slipper $v$ Turner [2015] ACTSC 27 (26 February 2015) [66].

${ }^{23}$ Jonathan Swan and Daniel Hurst, 'Expenses Critic Mark Dreyfus Embarrassed over Taxpayer Ski Trip to Perisher', Sydney Morning Herald (Sydney), 8 October 2013 http://www.smh.com.au/federal-politics/politicalnews/expenses-critic-mark-dreyfus-embarrassed-over-taxpayer-ski-trip-to-perisher-20131008-2v5sc.html.

${ }^{24}$ Hedley Thomas, 'Tim Mathieson's car use cost Julia Gillard \$4000', The Australian (Sydney), 17 September 2013 http://www.theaustralian.com.au/national-affairs/tim-mathiesons-car-use-cost-julia-gillard-4000/newsstory/6267159bdfa5d9748d1d2ea0b7c7f9ef.

${ }^{25}$ Stephanie Anderson and Ashlynne McGhee, 'Sussan Ley Defends Purchase of \$800k Unit on TaxpayerFunded Trip to Gold Coast', ABC News, 6 January 2017 http://www.abc.net.au/news/2017-01-06/leys-purchaseof-unit-on-taxpayer-funded-trip-not-planned/8165414.

${ }^{26}$ Department of Finance and Deregulation, Protocol Followed when an Allegation is Received of Alleged Misuse of Entitlement by a Member or Senator (tabled in the Senate by the then Special Minister of State on 31 October 2000). Available at: http://maps.finance.gov.au/docs/Protocol_on_Allegations.pdf.
} 
are investigated by the AFP. ${ }^{27}$ While numerous reviews and audits have identified that the remuneration and entitlements framework is 'complex' and difficult to understand and 'manage for both the Parliamentarians and relevant departments', ${ }^{28}$ politicians operate under a different system to ordinary members of the public. Indeed, while some federal ministers have been demoted due to expenses scandals, they are not subject to the same standards faced by other members of the public found to have misappropriated monies. This has been a cause of longstanding public concern.

Most recently, reports have emerged that former Speaker Bronwyn Bishop refused to cooperate with a 2015 Department of Finance review into her travel and related entitlements sparked by the revelation that she charted a $\$ 5227.27$ helicopter for travel from Melbourne to a Liberal Party function in Geelong in 2015. The Report indicates that Ms Bishop 'provided limited explanations of her reasons for claiming various entitlements, making it impossible for the department to verify whether her claims were a legitimate use of taxpayer dollars or not'. ${ }^{29}$ The Report explained that, as it 'is reliant on information provided by Mrs Bishop to fulfil its role in the exercise, no further assessment is possible in relation to the incomplete seven years'. ${ }^{30}$ The inadequacy of the Report, as well as meaningful accountability over broader misuse of entitlements, demonstrates several gaps in Australia's anti-corruption and integrity system with regard to federal parliamentarians. These include: a clear standard as to what conduct satisfies 'misconduct' or 'corruption'; strong enforcement powers enabling the compulsion of documents; consequences for breaching standards; and the absence of an effective mechanism for addressing conduct once the member in question has left Parliament. Additionally, as this report was only revealed via a Freedom of Information request, transparency surrounding investigations is lacking. A requirement to make findings public, or to hold public hearings, would increase the likelihood of meaningful accountability.

Changes to the existing regime have been implemented, but they appear unlikely to be particularly effective. In February 2017, in the wake of another parliamentary entitlements

\footnotetext{
${ }^{27}$ Peter Slipper was a notable exception; though the case was dismissed on appeal: Slipper v Turner [2015] ACTSC 27 (26 February 2015).

${ }^{28}$ Australian National Audit Office, Parliamentarians' Entitlements 1999-2000 (Audit Report No 5, 7 August 2001) 17 [15]; Australian National Audit Office, Administration of Parliamentarians' Entitlements by the Department of Finance and Deregulation (2009); Commonwealth of Australia, Committee for Review of Parliamentary Entitlements, An Independent Parliamentary Entitlements System: Review (February 2016) 1-2 [5]-[6].

${ }^{29}$ Latika Bourke, 'Bronwyn Bishop cut short participation in expenses review after repaying more than $\$ 6700$, report reveals', Sydney Morning Herald (Sydney), 30 March 2017 http://www.smh.com.au/federalpolitics/political-news/bronwyn-bishop-cut-short-cooperation-with-expenses-review-after-repaying-more-than6700-report-reveals-20170329-gv9g8r.html.

${ }^{30}$ Department of Finance Report, Travel and Related Entitlements of the Hon Bronwyn Bishop: 1 July 2005-30 July 2015 (August 2016) 6 [1.11].
} 
controversy that culminated in Health Minister Sussan Ley's resignation, the Commonwealth Parliament established an Independent Parliamentary Expenses Authority (IPEA), ${ }^{31}$ based on the model used by the United Kingdom. Its functions include administering and overseeing the work expenses of parliamentarians and ministers.

Persons are required to give the Authority information or documents relevant to its reporting and auditing functions, which includes material relating to work and travel expenses. ${ }^{32} \mathrm{~A}$ criminal penalty may be levied for contravening this requirement. However, such a penalty can be excused if it 'might incriminate the person or expose the person to a penalty'. ${ }^{33}$ Consequently, the IPEA is not able to impose sanctions for failing to comply with an order to provide documents. The IPEA therefore has weaker powers than many civil regulators whose statutory regimes do not allow people to refuse on the basis of a privilege against selfincrimination.

Further, in the case of a breach of expenses, it is not clear what avenues the IPEA could pursue other than recovery of payments. This contrasts to the situation in the UK where the Independent Parliamentary Standards Authority (IPSA) operates within a stronger integrity regime. Members of Parliament entitlement claims are published online every two-months, and are searchable via an interactive map. ${ }^{34} \mathrm{~A}$ statutory compliance officer has the authority to review IPSA's decisions about claims, and publishes all investigations into allegations of misuse of entitlements online. ${ }^{35}$ In addition to recovering overpayments to parliamentarians, the compliance officer has the authority to impose penalties on Members 'for failing to comply with a request for information or a repayment direction'. ${ }^{36}$ A Member of Parliament who knowingly makes a false or misleading claim is liable for 12 months imprisonment. ${ }^{37}$

Despite the introduction of the IPEA, Australia's anti-corruption and integrity system still lacks an effective mechanism for holding federal politicians accountable at the same standards as other members of the public. Certainly, the IPEA could be reformed in line with the powers of the UK IPSA, which operates under an enhanced transparency regime, and with considerable powers of enforcement and sanction. However, a better approach would be the

\footnotetext{
${ }^{31}$ Independent Parliamentary Expenses Authority Act 2017 (Cth).

${ }^{32}$ Independent Parliamentary Expenses Authority Act 2017 (Cth) s 53

${ }^{33}$ Independent Parliamentary Expenses Authority Act 2017 (Cth) s 55.

${ }^{34}$ Independent Parliamentary Standards Authority, 'MP Costs: Interactive Map' http://www.theipsa.org.uk/mpcosts/interactive-map/.

${ }^{35}$ Compliance Officer for Independent Parliamentary Standards Authority, 'Completed Reviews', http://www.parliamentarycompliance.org.uk/transparency/Pages/completed-reviews.aspx.

${ }^{36}$ Independent Parliamentary Standards Authority, IPSA's First Parliament 2010-2015: Regulation, Support, and Remuneration (May 2016) 17 [60].

${ }^{37}$ Parliamentary Standards Act 2009 (c 13) s 10.
} 
introduction of a national integrity commission with authority over federal parliamentarians. As we note in the final section, a single body can develop investigatory and policy expertise, as well as provide leadership and confidence within the community that corruption is being dealt with. As a prominent, one-stop-shop, it would also encourage greater reporting of allegations, reducing corruption throughout the federal government.

\section{Effect of gaps in Australia's anti-corruption system}

Surveys indicate that the share of Australians who trust in government has fallen. For instance, the global 2017 Edelman Trust Barometer found that Australians' trust in government fell by 8 points between 2016 and 2017. ${ }^{38}$ Likewise, empirical work by the University of Canberra's Institute for Governance and Public Analysis and the Museum of Australian Democracy released in 2016 has found that trust in government and politicians is now at the lowest levels in over two decades, indicating that 'only 42 per cent of Australians are happy with the way democracy works in the country'. ${ }^{39}$ Sarah Cameron and lan McAllister's long-running Trends in Australian Political Opinion reveals a similar result. Cameron and McAllister found that since 2007, trust in government has fallen 17 points, and the percentage of people satisfied with democracy has dropped 26 points. ${ }^{40}$ These results are also reflected in Scanlon Foundation surveys, which, since 2010, 'have registered continuing low level of trust in the federal parliament'. ${ }^{41}$ While declining trust in government is a global phenomenon and a result of multiple causes, Australia's inadequate anti-corruption and integrity system is fuelling concerns. Recurring parliamentary expenses scandals trigger 'a public loss of faith in [Parliament] and its members', ${ }^{42}$ 'destroying public confidence in the integrity of Parliament'43 and have a 'corrosive effect' on democracy. ${ }^{44}$

Trust in government is integral for good governance and social cohesion. A 2013 OECD Report highlighted trust in government as a determinant of effective functioning of democracy:

\footnotetext{
${ }^{38} 2017$ Edelman Trust Barometer, 'Global Results: ‘Trust in Government Further Evaporates’ 13 http://www.edelman.com/global-results/.

${ }^{39}$ University of Canberra, 'Trust, An Absent Commodity in this Election: UC-IGPA', 24 June 2016 http://www.governanceinstitute.edu.au/news-and-media/news/104/trust-an-absent-commodity-in-this-electionuc-igpa.

${ }^{40}$ Sarah Cameron and Ian McAllister, Trends in Australian Political Opinion: Results from the Australian Election Study 1987-2016 (ANU Press, 2016) 74-75.

${ }^{41}$ Andrew Markus, Mapping Social Cohesion: The Scanlon Foundation Surveys 2016 (Scanlon Foundation, 2016) 3 .

42 'Pollies Caught Out by Public Expectations', The Australian (Sydney), 26 May 2012, 15 cited in Blackham and Williams, above n 19, 131.

${ }^{43}$ Phillip Hudson, 'High Time for an Umpire in Parliament', Herald-Sun (Melbourne), 25 May 2012, 39.

${ }^{44}$ Amanda Lohrey, 'Comment: Australian Democracy and the Right to Party', The Monthly (July 2012
} 
Trust in government has been identified as one of the most important foundations upon which the legitimacy and sustainability of political systems are built. Trust is essential for social cohesion and well-being as it affects governments' ability to govern and enables them to act without having to resort to coercion. Consequently, it is an efficient means of lowering transaction costs in any social, economic and political relationship. ${ }^{45}$

It is critical that Australia arrest the decline in faith in our democratic institutions. Revamping our under-inclusive and unwieldy anti-corruption and integrity system is a central element of this strategy.

\section{How can this be fixed?}

Australia's national corruption framework is under-inclusive and unwieldy. Our article has identified two major problems with the existing multi-agency approach: the multiplicity of agencies responsible for investigating allegations of corrupt conduct make it difficult for individuals to know to which body they should address their allegations, and the absence of an effective mechanism to hold federal parliamentarians to account detracts from Australia's commitment to good governance.

A national whole-of-government anti-corruption body, able to apply a uniform standard of corrupt conduct across all parts of government, offers the best hope for rectifying these problems. Such a body will operate as a 'one-stop-shop', providing a clear path for persons with information about alleged corrupt conduct to report; coordinate prevention, risk assessment and monitoring activities; and eliminate gaps in the existing regime. As the 2016 Interim Report of the Select Committee on the Establishment of a National Integrity Commission noted, a national whole-of-government anti-corruption body has broad potential benefits:

While the most prominent function of a NAC [National Anti-Corruption Commission] is the discovery and investigation of corruption, a NAC may also improve policy co-ordination, provide leadership and education services, reduce potential jurisdictional gaps, increase administrative efficiency, send an unambiguous signal that the issue of corruption is being taken seriously, and

\footnotetext{
${ }^{45}$ OECD, Government at a Glance 2013 (2013) 21 (emphasis in original).
} 
provide confidence to the public that corruption is minimised at the highest level of government. ${ }^{46}$

As with state-based whole-of-government anti-corruption bodies ${ }^{47}$ the national body should also be tasked with an educative function. As the 2016 Interim Report identified, '[p]roviding education services surrounding corruption can increase the resilience of organisations and individuals to corruption, and clarify expectations around what does and does not constitute corrupt behaviours. ${ }^{48}$

Critics of a national integrity commission argue that its functions would overlap with other institutions already operating as part of the multi-agency approach. This is concerning because, as the Institute of Public Affairs has suggested, anti-corruption agencies can erode individual legal protections. ${ }^{49}$ Conversely, a single integrity body could be subject to budgetary pressures, shielding government in the face of allegations of corruption. These are both real concerns, but they can be managed. If properly designed and resourced, a national integrity commission would not weaken the rule of law or inappropriately shield government from accountability.

The case for whole-of-government anti-corruption bodies has proved overwhelming in the states. They are now in place in every state jurisdiction, and evidence suggests that they have been successful in revealing serious corruption. ${ }^{50}$ It is beyond time that a similar body is established at the federal level in Australia. ${ }^{51}$ At a time where trust in government and democratic institutions is falling precipitously, a national whole-of-government anti-corruption and integrity body, is sorely needed.

Harry Hobbs is a PhD candidate and Lionel Murphy Postgraduate Scholar at UNSW Law. George Williams is the Dean, Anthony Mason Professor and Scientia Professor, UNSW

\footnotetext{
${ }^{46}$ Select Committee on the Establishment of a National Integrity Commission, Commonwealth of Australia, Interim Report (2016) 27 [3.71].

${ }^{47}$ See, eg, Independent Commission Against Corruption Act 1988 (NSW) s 13(1)(h).

${ }^{48}$ Select Committee on the Establishment of a National Integrity Commission, above $n$ 46, 27 [3.72].

${ }^{49}$ Evidence to Select Committee on the Establishment of a National Integrity Commission, Parliament of Australia, Canberra, Canberra, 21 April 2016, 19 (Mr Simon Breheny, Director of Policy, Institute of Public Affairs).

${ }^{50}$ See, eg, ICAC, Investigation into NSW Liberal Party Electoral Funding for the 2011 State Election Campaign and Other Matters (August 2016).

${ }^{51}$ For a major paper canvassing key issues for the design of a federal anti-corruption commission see Gabrielle Appleby and Grant Hoole, 'Integrity of Purpose: Designing a Federal Anti-Corruption Commission' (Transparency International, Discussion Paper No 1 - Strengthening Australia's National Integrity System: Priorities for Reform, 17 March 2017) 6-33.
} 
Law. This article is based upon a submission the authors made to the Senate Select Committee on a National Integrity Commission, dated 4 April 2017. 